\title{
GLOBALNE I EUROPEJSKIE DETERMINANTY WPR
}

\begin{abstract}
Abstrakt
Podstawowym celem artykułu jest przedstawienie wybranych uwarunkowań globalnych $i$ wewnatrzeuropejskich projektowania, prowadzenia, aktualizacji i reformowania wspólnej polityki rolnej (WPR) Unii Europejskiej. Uwarunkowania te tworza dynamiczny układ interakcji o charakterze komplementarnym (synergie), ale i sprzecznym (wymienności). Do tego dochodza samoistne dylematy WPR, typowe dla każdej sektorowej polityki gospodarczej. Takie szerokie spojrzenie uzasadnione jest pogłębiającymi się wspótzależnościami we współczesnym świecie i znaczeniem UE jako największego aktora ekonomicznego w ujecciu globalnym. WPR z kolei jest przedmiotem stałego zainteresowania innych krajów jako źródło inspiracji, ale też przestroga, jeśli chodzi o niepożadane skutki rozległego interwencjonizmu państwowego.

Artykut jest studium przekrojowym, majacym jednak pewne cechy metaanalizy, w którym zsyntetyzowano dorobek innych badaczy i przemyślenia własne autora. Z całości rozważań wynika, że WPR - od lat odwołujaca sie do paradygmatów zrównoważenia $i$ wielofunkcyjności rolnictwa - ma znamiona konstrukcji w miare nowoczesnej, utylitarnej $i$ zorientowanej na przyszłość. Jednak jej silne poleganie na subsydiach czyni ja propozycja mało atrakcyjna dla większości krajów rozwijajacych się, utrudniając im wręcz. rozwiazywanie poważnych problemów rozwojowych. Subsydia rolne deformuja również konkurencję na międzynarodowych rynkach rolno-żywnościowych. Osłabiaja ponadto motywację rolników unijnych, by starali się poprawiać swoja pozycje konkurencyjna przez zachowania przedsiebiorcze, wdrażanie innowacji, staranne monitorowanie kosztów oraz adekwatne i elastyczne strategie operacyjne, finansowe $i w$ zakresie zarzadzania ryzykiem.
\end{abstract}

Słowa kluczowe: Wspólna Polityka Rolna (WPR), gobalizacja a rolnictwo, ewaluacja i determinanty polityki rolnej 


\section{Wprowadzenie}

Projektowanie, prowadzenie, aktualizacja i reformowanie WPR to złożony proces, wielorako uwarunkowany, kształtowany przez wielu aktorów polityczno-ekonomicznych i zorientowany na kilka celów, jednak tylko w części autonomiczny wobec sił globalnych. Niektóre z tych determinant, ważnych w subiektywnej ocenie autora, zostaną przedstawione w poniższym artykule. Jest to zatem jego podstawowy cel. Oczywiście, nie będzie to jakieś całościowe ujęcie, gdyż czynniki globalne, europejskie oraz krajowe wchodzą w rozmaite, dynamiczne interakcje, głównie w postaci synergii i wymienności, nie do końca jeszcze rozpoznane, nie mówiąc już o ich modelowaniu. Wprawdzie główna uwaga zostanie skoncentrowana na ich implikacjach dla konkurencyjności unijnego sektora żywnościowego, ale kategorię tę będzie traktować się jednocześnie jako proces oraz wynik w sposób wysoce instrumentalny, tzn. jako środek prowadzący do osiągania wyżej usytuowanych celów społeczno-ekonomicznych.

\section{Determinanty globalne}

Jest ich wiele, ale do najważniejszych można zaliczyć poniżej wymienione:

1. Prawdopodobny jest znaczniejszy przyrost liczby ludności niż dotychczas przypuszczano; ok. 9 mld przewidywano w roku 2050, ale populacja ta może stale się zwiększać, osiągając w końcu bieżącego stulecia poziom 12-13 mld. Nadal presja demograficzna najsilniejsza będzie w tzw. krajach rozwijających się, głównie w Afryce. Ogólnoświatowym problemem będzie natomiast ciągły wzrost odsetka osób z nadwagą i dotkniętych otyłością. Według najnowszych danych Światowej Organizacji Zdrowia (WHO) z lipca 2015 roku, ludzi takich jest już 2,1 mld, a roczne negatywne skutki z tym związane kosztują społeczność światową ok. 2 bln USD (Kowalski, 2012). Dzieje się tak w warunkach powolnego, ale systematycznego spadku liczby ludzi cierpiących głód, których aktualnie - wg ONZ - jest ok. 795 mln. Niestety, wciąż ok. 2 mld Ziemian ma w swej diecie zbyt mało mikroelementów.

2. Należy spodziewać się co najwyżej umiarkowanego wzrostu gospodarczego mierzonego za pomocą PKB. Przypuszczenie to najpełniej odzwierciedla tzw. hipoteza sekularnego spowolnienia, którą już w latach 30. ub. wieku sformułował A. Hansen, a ostatnio upowszechniana jest przez L. Summersa i P. Krugmana. Jej krytycy podnoszą statyczność ujęcia problemu, a więc abstrahowanie od innowacji jako głównego stymulatora poprawy produktywności całkowitej czynników produkcji. Warto bowiem szukać kombinacji działań zwiększających popyt globalny, łącznie z elementami redystrybucji i progresji podatkowej, propodażowych (wspierających innowacje i inwestycje modernizacyjne, w kapitał ludzki i społeczny oraz kompetencje kulturowe, a także poprawianie otoczenia prawno-regulacyjnego) i stymulujących zmiany w firmach. 
W tym ostatnim przypadku chodzi głównie o wydłużenie perspektywy oceniania podmiotów gospodarczych i wiązanie wynagrodzeń menedżerów z poprawą wyników długookresowych.

Na potwierdzenie słuszności hipotezy sekularnego spowolnienia można jednak podać zdecydowany spadek wzrostu gospodarczego w Chinach oraz poważne zaburzenia na tamtejszym rynku kapitałowym. Chiny, ze swoimi słabościami strukturalnymi w postaci bardzo wysokiej stopy oszczędności, przeinwestowaniem - zwłaszcza w infrastrukturze i budownictwie mieszkaniowym, samorządach i firmach - wysokim zadłużeniem rządu (ponad 200\% PKB) oraz dominacją firm państwowych i zanieczyszczeniem środowiska przyrodniczego, mogą być, przynajmniej w krótkim okresie, źródłem kłopotów dla gospodarki światowej. Dewaluacja chińskiego juana na początku sierpnia br. może wręcz wywołać tzw. wojny walutowe, a więc uciekanie się krajów do konkurencyjnych dewaluacji swoich walut. Czynnik ten, w połączeniu ze słabnącym wzrostem chińskiej gospodarki, doprowadzi do zmniejszenia globalnego popytu surowcowego, w tym także rolno-żywnościowego. Należy dodać, że w Chinach nadal ziemia rolnicza przypisana jest do „komun wiejskich” oraz „brygad robotniczych", co obniża racjonalne i efektywne jej użytkowanie.

Prognozowanie dynamiki gospodarczej w dłuższym okresie jest jednak bardzo ryzykowne. Nie dziwi zatem, że Międzynarodowy Fundusz Walutowy w ostatnich latach podaje stopę wzrostu PKB tylko na rok bieżący oraz przyszły. Z jego prognozy z lipca 2015 r. wynika, że dla całego świata w tym roku wyniesie ona $3,3 \%$, a więc mniej o 0,2 pkt proc. niż instytucja ta przewidywała jeszcze w kwietniu br. W roku 2016 świat będzie rozwijał się nieco tylko szybciej, bo w tempie $3,8 \%$. Nie powinno to zaskakiwać, gdyż brakuje już przestrzeni dla dalszego stymulowania monetarnego i fiskalnego gospodarek, a reformy strukturalne wdrażane są bardzo wolno. Przekładać się to będzie na co najwyżej umiarkowany wzrost dochodów, a więc i popytu. Spowolnieniu ulegnie także spadek liczby Ziemian żyjących w skrajnej biedzie, chociaż ludzkość odnotowała pod tym względem ogromny postęp. Według danych ONZ, podsumowujących stopień osiągnięcia tzw. Milenijnych Celów Rozwojowych, liczba takich ludzi zmalała z 1,9 mld (1990 rok) do 836 mln (2015). W tym samym okresie natomiast potroiła się liczba osób zaliczanych do klasy średniej. Tym samym zwiększać się prawdopodobnie będzie popyt na produkty pochodzenia zwierzęcego oraz żywność głębiej przetworzoną. Ma to istotne implikacje dla środowiska przyrodniczego, klimatu oraz gospodarowanie wodą słodką.

3. W walce $\mathrm{z}$ najświeższym kryzysem widoczne jest rozchodzenie się stóp wzrostu produktywności i opłaty pracy jako następstwo globalizacji, finansjalizacji i stymulacji monetarnej. Równolegle do tego następuje proces kurczenia się miejsc pracy dla ludzi o niskich i przeciętnych kwalifikacjach (tzw. prekaryzacja). Dzieje się tak z powodu postępującej cyfryzacji i robotyzacji, rozpowszechniania się internetu oraz big data. Szczególnie trudna na rynku pra- 
cy jest sytuacja osób młodych. Trudno jest więc wyraźnie zwiększyć zagregowany popyt efektywny, w tym także żywnościowy, i trwale przywrócić szybki wzrost gospodarczy. Potrzebne byłyby do tego działania bardziej zorientowane na wzrost płac, rozsądną redystrybucję dochodów i majątku oraz czasu pracy, osłabienie roli menedżerów i właścicieli, a także ograniczające możliwości optymalizowania i unikania podatków przez korporacje transnarodowe i ludzi bogatych. Optymalizacja taka jest elementem szerszego zjawiska: offshoringu, a więc przenoszenia za granicę różnych aspektów działalności biznesowej w celu redukcji kosztów i poprawy konkurencyjności. Socjologowie społeczni problem ten widzą jednak jeszcze inaczej, a mianowicie jako formę ucieczki przed wszelkimi zobowiązaniami, zrywania więzi społecznych oraz pogłębiania nierówności. Ma to być nawet podstawowe pole współczesnej walki klas. Na pewno jest to jeden z negatywnych skutków globalizacji. W tym kontekście być może trzeba wręcz wdrożyć koncepcję dochodu podstawowego F.A. von Hayeka i M. Fridmana, a więc otrzymywanego przez każdego obywatela pracującego bądź nie.

4. Rokowania WTO w ramach rundy w Doha od kilku lat znalazły się w głębokim impasie. Równolegle do tego coraz częściej zawierane są umowy dwustronne i regionalne. To jasny dowód na brak wystarczającej koordynacji ogólnoświatowej polityki społeczno-ekonomicznej, w tym rolno-żywnościowej. Cierpi na tym przejrzystość subsydiowania rolnictwa oraz deformuje się konkurencyjność na globalnych rynkach rolno-żywnościowych, m.in. przez praktyki dumpingu socjalnego oraz środowiskowego. W konsekwencji konkurencja ta jest głównie grą o sumie zerowej, gdy tymczasem światu potrzeba więcej zachowań typu „win-win”, a więc jakiegoś połączenia konkurencji z kooperacją.

5. Do stosunków międzynarodowych powróciła Realpolitik oraz historia i geopolityka. Stało się tak w wyniku konfliktu na Ukrainie, ekspansji Państwa Islamskiego oraz agresywnych zachowań Chin na Morzach Południowoi Wschodnio-chińskich, a także zapowiedzi zrewidowania polityki pacyfizmu przez Japonię i Niemcy. W ślad za tym nasilać się będą napięcia między bezpieczeństwem żywnościowym, zewnętrznym, socjalnym i energetycznym. Konkurencja pojawi się także w sferze dostępu do funduszy publicznych. Cykl sankcje-kontrsankcje-resankcje w stosunkach Zachód-Wschód/Niezachód może z kolei ulec eskalacji i utrwaleniu. Zaostrzy to konkurencję w międzynarodowym handlu rolno-żywnościowym, a na znaczeniu zyskają jeszcze bardziej tradycyjne przewagi bazujące na niskich kosztach wytwarzania. Dla Europy konflikty zbrojne $\mathrm{w}$ jej bliższym i dalszym otoczeniu stwarzają bardzo poważny problem z imigrantami, szczególnie pochodzącymi z Afryki i Bliskiego Wschodu. Jak już wspomniano, Afryka wyróżnia się największą dynamiką przyrostu naturalnego. Z prognozy ONZ z lipca br. wynika, że liczba Afrykanów wzrośnie z 1,2 mld obecnie do 4,3 mld w $2100 \mathrm{r}$. 
6. Klimat, energia, gospodarka niskoemisyjna i cyrkulacyjna (bezodpadowa) oraz zielony wzrost i rozwój społeczno-ekonomiczny tworzą zbiór zjawisk i problemów coraz silniej wzajemnie powiązanych i uwarunkowanych. Ograniczając się jednak do klimatu i jego związku z emisją gazów cieplarnianych, spowodowanych działalnością człowieka, trzeba stwierdzić, że aktualnie ok. 2/3 światowej emisji dwutlenku węgla przypada na kraje rozwijające się, z Chinami na czele (28\% udziału). Kraje te, podobnie jak USA, Kanada i Australia, były dotychczas niechętne zawarciu globalnego porozumienia klimatycznego. Jest pewna nadzieja, że może się to zmienić, gdyż USA i Chiny dobrowolnie zadeklarowały cele redukcyjne. Być może zatem konferencja klimatyczna, która odbędzie się na przełomie listopada i grudnia 2015 roku w Paryżu, zakończy się sukcesem, tj. podpisaniem ogólnoświatowej umowy o redukcji emisji dwutlenku węgla. Obejmie ona z pewnością także rolnictwo, które obecnie odpowiedzialne jest za ok. 13\% emisji gazów cieplarnianych (Nowa polityka rolna..., 2014). Wymagać to będzie określonych działań adaptacyjnych i mitygacyjnych, których koszty przełożą się prawdopodobnie na krótkookresowy spadek konkurencyjności w niektórych krajach.

7. Być może mają rację ci, którzy uważają, że już od zakończenia drugiej wojny światowej ludzkość przeszła faktycznie w epokę geologiczną nazywaną antropocenem. Pojęcie to odzwierciedla dominujący wpływ człowieka na funkcjonowanie przyrody, wyczerpywanie się jej zasobów, emisję gazów cieplarnianych prowadzącą do przyspieszenia zmian klimatu oraz emisje innych szkodliwych substancji. Następstwem tego ma być: ujednolicenie gatunków żyjących na Ziemi, ulokowanie się człowieka na szczycie łańcuch troficznego, co implikuje jego niekwestionowany wpływ na ewolucję innych gatunków, oraz coraz wyraźniejsze przenikanie biosfery przez technosferę, tzn. kontrolowanie życia na Ziemi przez maszyny i urządzenia stworzone przez człowieka (Ulanowski, 2015). Żyjemy zatem na kredyt/koszt przyszłych pokoleń, zaostrzamy konkurencję o zasoby nieodnawialne i odnawialne oraz przyspieszamy proces szóstego już powszechnego wymierania gatunków. Musimy być też przygotowani na to, że przyroda sama spróbuje przywrócić równowagę, doprowadzając np. do wybuchu jakiejś pandemii. Lepiej temu zaradzić, przyjmując w skali świata kurs na wyraźniejsze zrównoważenie. Potrzebę takiej globalnej transformacji dostrzegło ONZ, proklamując ostatnio, iż Milenijne Cele Rozwojowe (MDG) zastąpi się Celami Zrównoważonego Rozwoju. Ich konkretyzację przewidziano na wrzesień 2015 roku. Obejmują całe spektrum aktualnych i przyszłych wyzwań przed światem (Stefanicki, 2015; The Millennium Development..., 2015).

8. Nawet przy założeniu, że w przyszłości dochody mieszkańców naszego globu będą rosły bardzo umiarkowanie, wydaje się, iż z racji szybkiego powiększania się ich liczby należy liczyć się ze wzrostem popytu rolno-żywnościowego. Sprawą otwartą jest natomiast, czy podaż będzie wystarczająca. W tym kontekście kluczowe znaczenie mają tendencje w zakresie zasobów ziemi rolniczej 
oraz wody słodkiej. Świat aktualnie dysponuje mniej niż 4,9 mld ha ziemi, ale co roku ubywa jej ok. $5 \mathrm{mln}$ ha. Bardzo mało jest gleb dobrych - ok. 3\%. W skali całego globu niewielkie są też możliwości zwiększenia areału użytków rolnych - rzędu 10\%, głównie w Azji Południowej, Afryce, Rosji i Ameryce Łacińskiej. Poważnym zagrożeniem jest również proces degradacji gleb wywołany erozją wodną i wietrzną, chemizacją rolnictwa i naturalnymi cyklami biologicznymi. Szacuje się, że obecnie na świecie ok. 2,8 mld ludzi (35\% całej populacji) dotkniętych jest tzw. ubóstwem wodnym, czyli jej niedostatkiem, spowodowanym czynnikami ekonomicznymi (Prandecki (red.) Z badań nad rolnictwem... (25), 2014). W roku 2030 może to dotknąć ok. 47\% populacji. Trzeba dodać, że rolnictwo jest największym ,konsumentem” wody słodkiej, z udziałem ocenianym na 60-70\% (Zegar, 2012). Wynika to głównie z rozwoju produkcji zwierzęcej i intensyfikacji nawożenia mineralnego, najczęściej połączonego z nawadnianiem gruntów. Próbując uogólnić te przykłady, można przyjąć, że podstawowym wyzwaniem dla rolnictwa światowego jest i będzie znalezienie rozwiązań dla równoczesnego wdrażania działań zorientowanych na zrównoważone powiększanie podaży produktów rolno-żywnościowych oraz zracjonalizowanie i zredukowanie popytu, głównie przez zmianę diety, redukcję strat czy praktyczne wdrożenie technologii produkcji biopaliw drugiej i kolejnych generacji. Daje to szansę złagodzenia napięcia między dotychczasowym modelem osiągania bezpieczeństwa żywnościowego a narastającymi problemami środowiskowymi, postępującą zmianą klimatu oraz utratą bioróżnorodności.

\section{Determinanty europejskie}

Według informacji demografów z Uniwersytetu Stanu Waszyngton w Pullman z września 2014 r., w Europie mieszkało wówczas 740 mln ludzi, ale pod koniec b. wieku ma być nas mniej o ok. $14 \mathrm{mln}$. Zdecydowanie bardziej pesymistyczna jest prognoza demograficzna ONZ z lipca br. Wynika z niej, że Stary Kontynent w 2100 r. zamieszkiwać będzie ok. 646 mln obywateli. Europa jest zatem kontynentem starzejących się ludzi, z problemami ze wzrostem gospodarczym i miejscami pracy dla młodych, broniącym modelu państwa dobrobytu przed globalizacją, bazującym na wysokim zadłużeniu publicznym i prywatnym, a ostatnio z zagrożonym poczuciem bezpieczeństwa zewnętrznego. To region, w którym stare kraje członkowskie UE stosują nieuczciwą konkurencję podatkową, w czym przodują Cypr, Irlandia, Holandia i Luksemburg, nie stronią od tego także Austria, Belgia i Wielka Brytania. Z kolei kraje nowe uciekają się do tzw. wyścigu do dna, by przyciągnąć kapitał zagraniczny, cierpi jednak na tym m.in. środowisko naturalne. Bruksela głęboko sięga też w konkurencyjność, m.in. przez Procedurę Nierównowagi Makroekonomicznej. Paradoksalnie jednak to wciąż miejsce, swoisty raj na ziemi, dla milionów biedaków z Afryki, Bliskiego Wschodu i Azji. Ich integracja z Europejczykami będzie jednak długim i bardzo złożonym procesem. 
UE całkiem nieźle radzi sobie z redukcją deficytów budżetowych (z 24 krajów objętych procedurą nadmiernego deficytu zostało 10), ale gorzej już z długiem publicznym. W całej UE jest on obecnie wyższy niż w roku 2007, przy czym w 11 krajach wzrost ten jest dwukrotny. Grecja i Włochy to na dobrą sprawę bankruci. UE wprowadziła wprawdzie dwupak, sześciopak i pakt fiskalny, by wzmocnić Pakt Stabilności i Wzrostu, ale Francja i Włochy i tak go nie przestrzegają. Nie zanosi się, by kraje te spotkały z tego powodu jakieś sankcje. Największym problemem jest i pozostanie bez wątpienia kwestia nierównowagi ekonomicznej i niestabilności strefy euro. Za sprawą Grecji widać coraz wyraźniej, że nie da się wykluczyć wręcz katastroficznego scenariusza rozwoju sytuacji, a więc całkowitego rozpadu Eurolandu. Trzeba by wtedy dołożyć wszelkich starań, by nadal funkcjonowała sprawnie UE i jednolity rynek oraz strefa Schengen. Ta ostatnia jest poważnie zagrożona przez ogromny napływ imigrantów.

W UE wszyscy chcą naśladować Niemcy, Austrię, Holandię, Chiny i Japonię, tzn. eksportować, eksportować i jeszcze raz eksportować. Tylko kto będzie importował? W samych Niemczech ekspansja eksportowa poprzedzona była deregulacją rynku pracy, co pogłębiało jeszcze proces nierówności dochodowych. Model eksportowy zachęca do praktyk ,puszczania sąsiadów w skarpetkach", a więc wyniszczających w końcu wszystkich. Szybko też zderzy się z barierą realnego popytu. Nie należy zatem oczekiwać, by efektywny popyt konsumpcyjny w UE rósł w przyszłości w zauważalnym tempie. Konkurencja wewnątrzeuropejska na rynku rolno-spożywczym będzie więc ostra, zwłaszcza w zakresie produktów masowych, którymi są głównie nieprzetworzone surowce rolnicze. Bardzo dobrze widoczne było to $\mathrm{w}$ protestach francuskich rolników z lata br., którzy blokowali transport żywności m.in. z Polski. Wzrośnie zatem jeszcze bardziej znaczenie niskich kosztów produkcji jako podstawowej przewagi konkurencyjnej.

EBC i fundusze unijne stabilności finansowej zapobiegły wprawdzie rozpadowi Eurolandu w latach 2011-2012, zasadnicze problemy nie zostały jednak zadowalająco rozwiązane. Bardzo powoli poprawia się kondycja banków, ale główny ciężar polityki stabilizacyjnej wciąż ponosi polityka monetarna. Kruchy wzrost, przeplatany okresowo płytkimi recesjami, realne zagrożenie deflacyjne stale spychają EBC w kierunku podejmowania działań niestandardowych, których skutki są nieznane. Na aktywniejszą politykę fiskalną trudno liczyć ze względu na wysokie zadłużenie publiczne, a reformy strukturalne ,idą jak po grudzie". Sporadycznie mówi się dziś o unii fiskalnej, koniecznej dla kompletności strefy wspólnej waluty, i o głosowaniach większościowych zamiast jednomyślności. W Eurolandzie pęcznieje coraz bardziej bańka spekulacyjna na rynku obligacji. Być może eurostrefa i cała UE bieżącą dekadę będą musiały spisać na straty. Dla krajów poza Eurolandem zagrożeniem są mechanizmy płynnościowe dla banków „19”, ale przede wszystkim oddzielny budżet. Płyną z tego następujące wnioski: 
- popyt globalny, a szczególnie konsumpcyjny w UE i Eurolandzie w najbliższych latach będzie raczej stabilny, aczkolwiek wykluczyć nie da się jego spadku, co wzmacniać będzie konkurowanie na bazie niskich kosztów i rozsądnej ich proporcji do jakości;

- peryferia Eurolandu dokonały dużego postępu w zakresie tzw. dewaluacji wewnętrznej, której skutkiem jest m.in. spadek jednostkowych kosztów pracy. W ten sposób rośnie ich konkurencyjność w eksporcie;

- na skutek zaprzestania luzowania ilościowego polityki pieniężnej przez amerykański bank centralny (Fed) można oczekiwać deprecjacji euro, co może stanowić dodatkowy impuls dla eksportu, chociaż efekt ten rozmaicie rozłoży się na kraje Eurolandu i znajdujące się poza nim. Te ostatnie jednak mają mały margines wpływania przez swą politykę pieniężną za pośrednictwem tzw. kanału kursowego na wzrost gospodarczy, inflację i eksport. W coraz większym stopniu kurs ich waluty określany jest przez czynniki globalne oraz przez działalność korporacji transnarodowych;

- środowisko niskich stóp procentowych utrzyma się prawdopodobnie przez dłuższy czas, co preferować będzie konsumpcję kosztem oszczędności i inwestycji oraz deformować będzie wybory w zakresie opłacalności przedsięwzięć rozwojowych.

UE chce być liderem w zakresie przeciwdziałania zmianom klimatycznym i w promowaniu gospodarki niskoemisyjnej. Kwestie energetyczno-klimatyczne we Wspólnocie reguluje Plan 2050. Przewiduje on m.in., że do roku 2050 UE chce zredukować emisję $\mathrm{CO}_{2}$ o $80 \%$ w stosunku do roku 1990. Plan ten realizowany jest za pomocą tzw. pakietów obejmujących jedną dekadę. Obecnie obowiązuje pakiet z 23.04.2009 określany jako Pakiet 3x20, który kończy się w roku 2020. Po roku 2020 mają obowiązywać rozwiązania przyjęte w październiku 2014 r. Przewidują one w stosunku do 2005 r. osiągnięcie w 2030 roku:

- redukcji $\mathrm{CO}_{2}$ o $40 \%$ (43\% w branżach: energetyka i przemysł, czyli objętych systemem handlu uprawnieniami do emisji (ETS), oraz 30\% w sektorach poza ETS, do których zalicza się: rolnictwo, transport, budownictwo). Trzeba dodać, że sektory poza ETS emitują 60\% gazów cieplarnianych;

- wzrostu udziału odnawialnych źródeł energii (OZE) do $27 \%$ i poprawę efektywności energetycznej też o $27 \%$. Są to cele nieobligatoryjne.

Oceniając powyższe zamierzenia, trzeba wskazać, że:

- zawarte w Pakiecie 2021-2030 różnorodne rozwiązania dla UE-15 i UE-13 deformować będą wewnątrzunijną konkurencję, ale zgodzono się na to w imię solidarności europejskiej;

- w krótkim okresie Pakiet oznaczać będzie koszty i wyrzeczenia, ale w okresie dłuższym powinien sprzyjać innowacjom, postępowi technicznemu, wzrostowi niezależności energetycznej UE, nowym miejscom pracy i reindustrializacji na nowej podstawie. Pamiętajmy, że 6 polskich miast należy do „10” najbardziej zanieczyszczonych w UE; 
- potrzebny jest jednak daleko idący pragmatyzm, zwłaszcza w zakresie subsydiowania OZE, oraz dbanie o to, by w UE nie pojawiło się na szeroką skalę tzw. wykluczenie energetyczne;

- UE liczy, że Pakiet da impuls do zakończenia sukcesem konferencji klimatycznej w Paryżu;

- co do redukcji emisji gazów cieplarnianych w samym rolnictwie, brakuje jeszcze jasności, jak ma to być w praktyce osiągnięte.

Prawdopodobne jest wyjście Wielkiej Brytanii (tzw. Brexit) z UE. Sprawa ta rozstrzygnie się w roku 2016, a najpóźniej w 2017 roku. Nie wiemy jednak, jak na to zareagowaliby Irlandczycy, Duńczycy i Szwedzi. Sprawą otwartą jest także przyszłość Grecji. Nie wolno zapominać, że Brytyjczycy są trzecim płatnikiem netto do unijnego budżetu (w 2013 r. było to 8,5 mld euro). Wynikało to $\mathrm{z}$ relatywnie niskiego wsparcia dla rolnictwa w tym kraju i stosunkowo małej pomocy strukturalnej. W powyższym kontekście warto zauważyć, że:

- tradycyjnie Brytyjczyków postrzega się jako zwolenników liberalizmu gospodarczego i wolnego handlu. Domaganie się przez nich ograniczeń w swobodnym przepływie osób kłóci się wyraźnie jednak z tym wyobrażeniem;

- ewentualne wyjście W. Brytanii z UE spowoduje uszczerbek w dochodach budżetowych, a więc inni powinni go pokryć. W przeciwnym razie zwiększy się konkurencja o zredukowane fundusze;

- brak Brytyjczyków wzmocni grupę krajów popierających interwencjonizm rolny i rozwiązywanie problemów WPR głównie za pomocą subsydiów.

Wprawdzie pod koniec września 2014 r. UE podpisała wszechstronne porozumienie o handlu i gospodarce z Kanadą (CETA), ale wciąż trwają negocjacje podobnej umowy z USA (TTIP). 9 października 2014 r. państwa UE ujawniły swój mandat negocjacyjny dla KE w jej rozmowach z Amerykanami. Nie ma w nim nic np. na temat GMO, są natomiast zapisy dotyczące mechanizmów rozstrzygania sporów państwo-firmy. Konkretnie chodzi tu głównie o klauzulę ISDS (Investor-state dispute settlement). Ten instrument międzynarodowego prawa publicznego daje wprost nieograniczone możliwości pozywania pojedynczych krajów przez korporacje transnarodowe, co budzi ogromny niepokój w UE. Stanowi to obecnie najtrudniejszy problem w negocjacjach. Dodajmy, że jest to już trzecia próba zawarcia takiej umowy z USA. Poprzednie zakończyły się niepowodzeniem, m.in. z powodu blokady przez francuskie lobby rolne. Obecny traktat pierwotnie miałby wejść w 2016 r., co jest jednak nierealne, bo po obydwu stronach Atlantyku istnieją blokady polityczne, a przecież wszystkie parlamenty narodowe muszą ratyfikować tę umowę.

CETA i TTIP mają cele społeczno-ekonomiczne. Teoretycznie mogą zdynamizować handel, wzrost, zatrudnienie itd. Wymagany jest jednak dłuższy czas, by tak różne systemy się dostosowały, co dotyczy także rolnictwa. Wystarczy powiedzieć, że Amerykanie mają inną filozofię subsydiowania rolnictwa niż UE. 
Przykładowo:

- Amerykanie wspierają płynność i stabilizują cykl koniunkturalny w rolnictwie; bardzo dużą wagę przywiązują do subsydiowania ubezpieczeń rolniczych; zamiast prostych płatności rolno-środowiskowych mają m.in. instrument CRP (Conservation Reserve Program), aukcyjny, quasi rynkowy.

- W USA nie ma podatku VAT. Zamiast tego jest podatek obrotowy, ale nie we wszystkich stanach.

Płyną z tego dwie konkluzje:

- ewentualne ratyfikowanie CETA i TTIP oraz podobnych umów z Japonią i Koreą Południową znacząco poszerzy rynek, a więc i popyt;

- bardzo trudno jest w tym momencie przewidzieć nowych wygranych i przegranych. Każdy kraj z osobna musi przeprowadzić rachunek zysków i strat z przejęcia partnerstwa transatlantyckiego.

Konflikt na Ukrainie prawdopodobnie będzie trwał wiele lat. W konsekwencji i Rosja, i Ukraina, i wiele innych krajów b. ZSRR będą obszarem niestabilnym i ryzykownym, doświadczającym słabego wzrostu gospodarczego, a może i pogrążonym w kilkuletniej recesji, ze słabymi walutami. Dla unijnych eksporterów rolno-żywnościowych będzie to zatem rynek płytki, nadzwyczaj ryzykowny i mało opłacalny. Zaostrzy to pośrednio wewnątrzunijną konkurencję, co już jest bardzo widoczne np. na rynku wieprzowiny. Przekierowanie eksportu ze Wschodu na inne rynki z pewnością skomplikuje położenie oferentów żywności o niższych parametrach jakościowych, a więc np. polskich. Do tego dochodzą koszty transportu, utworzenia sieci sprzedaży i finansowania transakcji oraz ryzyka. Z drugiej natomiast strony, nie należy lekceważyć faktu, iż Ukraina już obecnie jest bardzo konkurencyjna w produkcji zbóż, słodyczy, oleju słonecznikowego i drobiu. Na pewno kraj ten skorzysta z preferencji zawartych w umowie stowarzyszeniowej z UE. Z kolei Rosja podejmie próby zwiększenia własnej produkcji rolnej, szczególnie zwierzęcej, bo w sektorze zbożowym - podobnie jak i Ukraina - jest już graczem globalnym. Jak przyznają jednak sami Rosjanie, nie będzie to ani łatwe, ani tanie, ani wreszcie szybkie.

Podsumowując tę część analizy, można powiedzieć, że przyszłe (po przeglądzie śródokresowym WPR, ale jeszcze bardziej po 2020 roku) decyzje o finansowaniu WPR prawdopodobnie ściśle zostaną powiązane $\mathrm{z}$ rozwiązaniem problemu imigracji, polityką energetyczno-klimatyczną oraz stosunkami z Rosją i Ukrainą. Być może zaostrzą się stanowiska starych i nowych członków Wspólnoty. Może się nawet zdarzyć, że „nowa Europa” nie otrzyma już takiego wsparcia od Niemiec, jak to miało miejsce dotychczas.

\section{Dylematy przed WPR}

WPR podlega ciągłej ewolucji, starając się dostosowywać swoje cele i instrumenty do zmian $w$ szeroko rozumianym otoczeniu, ale też reagując na krytykę krajów rozwijających się, iż deformuje ona światowy handel produkta- 
mi rolno-żywnościowymi, co utrudnia im wyrwanie się z zaklętego kręgu biedy i ubóstwa. Rolnictwo UE musi zatem obecnie stawać się coraz bardziej konkurencyjne i jednocześnie zintegrowane ze światem. Można na tym zyskać, ale trzeba się też liczyć z rosnącymi wahaniami koniunktury, zmiennością cen i kursów walutowych, a więc z rosnącą niepewnością i ryzykiem. Zwiększa się także nacisk ze strony konsumentów i obywateli, by w rolnictwie również racjonalnie użytkować wszelkie zasoby, dbać o bioróżnorodność, zapewniać znośne warunki chowu zwierząt itd. Rolnictwo szerzej musi się też włączyć w zapobieganie zmianom klimatycznym i udostępnianie źródeł ,zielonej energii” oraz biomateriałów. Ogólnie zatem, polityka rolna współcześnie i w przyszłości nie może się tylko koncentrować na celach ze sfery pomnażania i w miarę sprawiedliwego podziału dochodów rolniczych, lecz powinna stawać się polityką wzmacniającą międzynarodową konkurencyjność UE i krajów członkowskich w zakresie zadań mieszczących się w obrębie polityki środowiskowej, klimatycznej, energetycznej, technologicznej, ochrony konsumentów i zwierząt oraz światowej polityki żywnościowej. Z pola widzenia nie można także tracić kwestii związanych z kształtowaniem rozwoju wiejskiego i przestrzennego. Wyzwania powyższe i podstawowe na nie odpowiedzi zawiera zestawienie 1.

Fundamentem WPR już od kilkunastu lat są koncepcje zrównoważenia i wielofunkcyjności wsi i rolnictwa. Stanowią one dobre zabezpieczenie przyrodniczych podstaw budowy długookresowej konkurencyjności rolnictwa i całego sektora żywnościowego. Stale wymagają jednak redefiniowania i aktualizacji. WPR doprowadziła wprawdzie do zmniejszenia presji na środowisko przyrodnicze, jeśli wchodzi o nawożenie, a zwłaszcza zasoby wody słodkiej, ale nie da się tego w pełni powiedzieć w odniesieniu do środków ochrony roślin. Odnotowano też wyraźny postęp w redukcji emisji gazów cieplarnianych. Sporo jest jednak nadal do zrobienia w zakresie ochrony gleb, mimo przyjęcia w roku 2006 tzw. strategii tematycznej w tym obszarze. Szacuje się - przykładowo że $12 \%$ powierzchni lądowej UE dotkniętych jest erozją wodną, a $4 \%$ erozją wietrzną (Zegar (red.) Z badań nad rolnictwem... (23), 2014). 
Wyzwania stojące przed współczesna polityka rolna i sposoby ich rozwiązywania

\section{Zapewnienie wyżywienia ludzkości}

- trwałe podniesienie produktywności i efektywności rolnictwa

- wdrożenie rozwiązań dostosowanych do warunków krajowych

- wzmocnienie działań w badaniach rolniczych UE na rzecz rozwoju

\section{Wyżywienie, bezpieczeństwo i jakość żywności}

- inicjatywy wspierające zdrowe odżywianie się

- wspieranie produkcji wysokiej jakości

- wymiana informacji w całym łańcuchu żywnościowym

- wzmocnienie mechanizmów kontroli i sankcji

Konkurencyjność rolnictwa i sektora żywnościowego

- gromadzenie danych i śledzenie przeszłych zachowań w agrobiznesie

- wspieranie produkcji wysokiej jakości

- poprawa wsparcia eksportu, ale bez subwencji

- usunięcie niedostatków w stosowanych badaniach rolniczych

- zastąpienie wsparcia inwestycji wsparciem innowacji

- poprawa zarządzania ryzykiem cenowym i dochodowym

- koncepcje szerszego stosowania towarowych rynków terminowych

- analiza różnych możliwości łagodzenia skutków suszy

\section{Przystosowanie do zmian klimatycznych}

- poprawa systemu prognozowania

- wspieranie dostosowań technicznych

- wspieranie inwestycji w otoczeniu gospodarstw rolniczych

- ewentualne wsparcie rozwiązań ze sfery ubezpieczeń

\section{Zmniejszenie emisji z rolnictwa}

- rozwój i przetestowanie niskoemisyjnych technik i koncepcji produkcji

- ocena regulacji dotyczących nawożenia pod kątem skutecznego ograniczenia nadmiaru emisji azotu

- przedsięwzięcia strukturalne redukujące regionalne nadwyżki azotu

- wdrożenie koncepcji redukcji emisji z obszarów bagiennych w rolnictwie

- $\quad$ specyficzne przedsięwzięcia ochraniające wilgotne użytki zielone na glebach organicznych

\section{Zachowanie bioróżnorodności}

- uzgodnione programy międzynarodowe chroniące bioróżnorodność gatunkową i rasową

- monitorowanie i badanie bioróżnorodności krajobrazów rolniczych

- zachowanie i pielęgnacja ekstensywnych użytków zielonych

- obniżanie eutrofizacji wywołanej nawożeniem roślin rolniczych

\section{Rozwój obszarów wiejskich}

- jednoznaczne określenie odpowiedzialności i wzmocnienie wykorzystania funduszy na poziomie regionalnym

- koncentracja rządów na kompensacji finansowej, monitoringu i ocenie (ewaluacji)

- wdrożenie uzupełniających programów wsparcia na poziomie krajowym o charakterze ponadsektorowym i wzmacniającym konkurencyjność

Źródło: Opracowanie własne na podstawie: EU-Agrarpolitik nach 2013. Plädoyer für eine neue Politik für Ernährung, Landwirtschaft und ländlische Räume, „Berichte über Landwirtschaft”, Band 88, Nr 2, September 2010; Kurzstellungnahme zur Mitteilung der Europäischen Komission über die Ausgestaltung der Gemeinsamen Agrarpolitik bis 2020, „Berichte über Landwirtschaft”, Band 89, Nr 1, Mai 2011. 
W powyższym kontekście na głębszą refleksję zasługują przede wszystkim:

- możliwości poszerzenia obszaru komplementarności między jego ekonomicznym, ekologicznym i społecznym zrównoważeniem;

- brak przesłanek do deprecjonowania tradycyjnej mikroekonomicznej efektywności ekonomicznej i produktywności na rzecz rachunków zintegrowanych, gdyż ta właśnie efektywność i produktywność stanowią podstawę współczesnego konkurowania w wymiarze międzynarodowym. Jej znaczenie rośnie w warunkach pogorszenia się koniunktury gospodarczej i występowania ograniczeń popytowych. Z taką sytuacją mamy obecnie do czynienia. Stan ten może potrwać długo;

- rozluźnienie związku modelu z subsydiami;

- uznanie faktu, że równolegle istnieje także paradygmat wzrostu zrównoważonego gospodarstw rolniczych. Sformułowali go Escalante, Turvey i Barry (2009). Orzeka on, iż tempo sprzedaży tych gospodarstw nie powinno naruszać proporcji między kapitałem własnym a długiem. Akcentuje się tu zatem znaczenie krótko- i długookresowej równowagi finansowej, niezbędnej do trwania i rozwoju, a więc i zachowania zdolności do konkurowania;

- model unijny ogólnie nie jest atrakcyjny dla krajów biednych, a przez rozległe subsydiowanie może zakłócać wymianę międzynarodową, utrudniając tym krajom rozwiązywanie złożonych problemów rozwojowych. W tym sensie UE niewiele wnosi do złagodzenia skali niedożywienia części świata, aczkolwiek ma potencjał do zwiększenia produkcji rolnej i żywności.

Unijnemu modelowi zrównoważenia rolnictwa brakuje wyraźnego odwołania do paradygmatu systemowego. Zwracają na to uwagę m.in. Ripol-Bosch et al. (2012). W szczególności chodzi tu o brak siedmiu poniższych atrybutów systemu:

1) produktywności (zdolności dostarczania żądanego poziomu dóbr i usług);

2) stabilności (zachowania stałego poziomu produktywności przy normalnych warunkach funkcjonowania);

3) niezawodności (utrzymywania poziomu produktywności bliskiego równowadze przy wystąpieniu normalnych szoków);

4) odporności (powrót do równowagi lub poziomu produktywności zbliżonego do stanu wyjściowego po pojawieniu się serii zakłóceń);

5) adaptacyjności i elastyczności (umiejętność znajdywania nowych poziomów zrównoważenia lub kontynuacja dostarczenia korzyści przy długookresowych zmianach środowiska przyrodniczego);

6) równości (zdolność do sprawiedliwego podziału korzyści w obrębie danej generacji i w wymiarze międzygeneracyjnym);

7) autonomiczności (możliwość regulowania i kontrolowania interakcji z otoczeniem).

Stabilność, niezawodność i odporność to atrybuty w zasadzie bardzo zbliżone charakterem i można je bez uszczerbku połączyć w jedną cechę, czyli sta- 
bilność, a więc radzenie sobie systemu ze zmianami. Wraz z adaptacyjnością i elastycznością dają one możliwość analizowania rolnictwa jako systemu dynamicznego. Takiej perspektywy bardzo brakuje w dyskusjach na temat WPR, szczególnie w Polsce.

Model unijny tylko w części odpowiada na globalne wyzwania stojące przed sektorem żywnościowym. Istnieje w związku z tym kilka koncepcji względem niego konkurencyjnych oraz komplementarnych. W pierwszym rzędzie trzeba tu wymienić zrównoważoną intensyfikację (ang. sustainable intensification). Generalnie chodzi w niej o to, żeby zwiększyć produktywność jednostki ziemi, równocześnie redukując negatywne oddziaływania rolnictwa na przyrodę (Firbank, Elliot, Drake, Cao i Gooday, 2013; Franks, 2014; Godfray i Garnett, 2014; Godfray et al., 2010; Ripol et al., 2012; Smith, 2013). Drugą z koncepcji jest „rolnictwo inteligentne klimatycznie” (ang. climate-smart agriculture). To taki system, w którym w sposób zrównoważony podnosi się produktywność w rolnictwie, zwiększa jego odporność na emisję gazów cieplarnianych (adaptacja) i redukuje jej poziom (mitygacja), równocześnie poprawiając poziom narodowego bezpieczeństwa żywnościowego i skuteczniej osiągając założone cele rozwojowe (Beddington, 2012; The Hague Conference..., 2010).

Niewątpliwie bardzo interesujący jest model ,bezpiecznej przestrzeni operacyjnej" (ang. the safe operating space for interconnected food and climate systems). Ogólnie chodzi w nim o to, żeby znaleźć rozwiązania kompromisowe, które pogodzą kwestię maksymalizacji produkcji żywności w warunkach ograniczeń nakładanych przez wzrost liczby mieszkańców Ziemi oraz następstwa dla rolnictwa wynikające ze zmiany klimatu (Beddington, 2012). Wreszcie, trzeba wymienić i koncepcję tzw. zamknięcia luki produktywności (ang. closing the yield gap). Mamy tu w istocie nawiązanie do zrównoważonej intensyfikacji. Samą zaś lukę definiuje się jako różnicę między aktualną produktywnością ziemi i zwierząt a potencjalnie możliwą w danej lokalizacji, gdyby produkcja roslinna i zwierzęca prowadzona była w sposób optymalny (Franks, 2014; Godfray et al., 2010; Godfray i Garnett, 2014; Smith, 2013). Jasno z tego wynika, że w niektórych regionach świata należałoby zwiększyć np. plony ziemiopłodów, a w innych - zmniejszyć, redukując wcześniej nakłady, a więc intensywność gospodarowania.

Wiele kontrowersji wzbudza stosowany w unijnym rolnictwie system internalizacji powstających w nim efektów zewnętrznych oraz związany z tym sposób wynagradzania rolników za dostarczanie dóbr publicznych, zwłaszcza w postaci usług agrośrodowiskowych. W tym kontekście warto zwrócić uwagę na poniższe kwestie:

- należy starać się poszerzyć stosowane instrumentarium, a więc generalnie zredukować jego poleganie głównie na subsydiach;

- wynagradzanie za usługi agrośrodowiskowe powinno rekompensować koszty faktycznie poniesione i alternatywne, $\mathrm{z}$ niewielkim tylko komponentem 
motywacyjnym. Powinno się natomiast unikać w nim dodatkowego kanału redystrybucji dochodów (Endres, 2013; Fees i Seeliger, 2013; Glebe, 2001; Mußhoff i Hirschauer, 2011). Teoretycznie najwłaściwszą podstawą jest tu subsydium Pigou z 1920 roku, trudne jednak do wdrożenia w czystej postaci (Blankart, 2011; Brümmerhoff, 2011; Fritsch, 2014; Zimmerman, Henke i Broer, 2012);

- płatności agrośrodowiskowe i ewentualnie klimatyczne powinny być precyzyjniej adresowane, chociaż uwzględniające równocześnie ich koszty transakcyjne, co w sumie doprowadzi do efektywniejszej alokacji funduszy publicznych;

- subsydia nie powinny pozostawać w sprzeczności z proekologicznymi, samoistnymi motywacjami rolników (Sandel, 2012);

- rolnictwo tworzy koszty zewnętrzne zarówno w swojej działalności produkcyjnej, jak i w gospodarstwach domowych samych rolników. Koszty te, podobnie jak i korzyści zewnętrzne, powinny być zatem bilansowane i szacowane w całości. Trzeba to robić dla konsumpcyjnych i produkcyjnych efektów zewnętrznych oraz różnorodnych ich kombinacji. Przykładowo, w Polsce ocenia się, że tzw. niskie emisje gazów i pyłów, a więc pochodzące z domów jednorodzinnych (ok. 5 mln), których ponad $70 \%$ znajduje się na wsi, są znacznie groźniejsze niż tzw. wysokie, których źródłem jest przemysł.

Rolnictwo unijne polega już od lat głównie na subsydiach jako źródle finansowania bieżącego funkcjonowania i rozwoju. Wystarczy tu podać, że w Polsce w ostatnich latach dopłaty bezpośrednie (I filar) oraz wsparcie pozostałe (II filar) stanowią 60-65\% dochodu pieniężnego tworzonego w rolnictwie. Stare kraje Wspólnoty zdecydowanie preferują przy tym powyższe dopłaty, natomiast w nowych krajach obserwowano wyraźniejsze zrównoważenie struktury wsparcia. W całej UE wciąż problemem jest zróżnicowanie stawek płatności na 1 ha użytków rolnych, co przez niektórych uznawane jest za czynnik deformujący konkurencję we Wspólnocie. Kraje różnią się także pod względem stopnia odłączenia subsydiów od bieżących decyzji produkcyjno-inwestycyjnych rolników. Do kwestii tej dużą uwagę przywiązuje WTO, gdyż rozluźnienie związku między subsydiami a produkcją rolniczą ma zapewnić lepsze zrównanie konkurencji w wymiarze światowym. W tym miejscu trzeba dodać, że w nowej perspektywie budżetowej na lata 2014-2020 zmniejszono stopień odłączenia płatności budżetowych od produkcji. W rezultacie należy oczekiwać wzrostu tej ostatniej, co może utrudnić jej efektywne zagospodarowanie, szczególnie gdy wszyscy chcą głównie eksportować. Nie wolno przecież zapominać, że - jak to trafnie ujmuje J. Kornai - kapitalizm to gospodarka nadmiaru (Kornai, 2014). Dotyczy to także rolnictwa.

Bardzo silną zależność rolnictwa unijnego od subsydiów, podobnie jak większości krajów OECD, wyjaśniać można m.in. na gruncie ekonomii politycznej (Henning, 2002; Henning, 2005; Henning, 2008). Wygodnie jest przy tym 
operować efektywnością ekonomiczną i polityczną, a więc dążeniem polityków rolnych do maksymalizowania liczebności ich elektoratu, by w ten sposób zwiększyć swoje szanse na reelekcję. Dobrą ilustracją zależności między efektywnością polityczną i ekonomiczną WPR może być rysunek 1 . Wynika z niego, że największy rozdźwięk między nimi miał miejsce w okresie, gdy instrumentarium unijne koncentrowało się na regulowaniu cen rolnych, a więc gdy przejrzystość subsydiowania była mała. Wyraźny postęp pojawił się, tzn. spadła efektywność polityczna a poprawiła się ekonomiczna, kiedy wprowadzono dopłaty bezpośrednie połączone z produkcją rolniczą. Większa przejrzystość tych ostatnich dla konsumentów, podatników i zagranicznych konkurentów tworzyła dalszy nacisk na reformowanie WPR. Poważne bodźce do zmian pojawiły się po utworzeniu WTO (1994 r.) oraz po rozpadzie byłego bloku wschodniego i zadeklarowaniu przez UE chęci otwarcia się na nasz region. W tym to środowisku polityczno-instytucjonalnym zaczęły się w krajach należących do WTO upowszechniać płatności bezpośrednie odłączone, a więc teoretycznie neutralne wobec bieżącej produkcji rolniczej. W ten sposób rozwarcie między obydwoma rodzajami efektywności uległo dalszemu zmniejszeniu. Obecna perspektywa budżetowa UE może te korzystne procesy co najmniej zahamować, gdyż kraje członkowskie mają możliwość przeznaczenia do 15\% wsparcia bezpośredniego $\mathrm{w}$ formie płatności powiązanych z produkcją rolniczą.

Coraz bardziej potrzebny jest całościowy rachunek korzyści i kosztów związanych z subsydiami rolnymi, odwołujący się do zmian dobrobytu i koncepcji równowagi ogólnej. Powinien on obejmować:

- przyrost dobrobytu społecznego z racji przybliżenia optymalności prywatnej i społecznej oraz łagodzenia dysproporcji dochodowych, majątkowych oraz ze sfery równości szans w rolnictwie;

- straty dobrobytu z tytułu:

- efektów substytucyjnych i dochodowych oraz oszustw w zakresie korzystania z subsydiów i płacenia podatków oraz parapodatków,

- poboru podatków w celu sfinansowania subsydiów oraz kosztów transakcyjnych związanych z obydwoma tymi instrumentami fiskalnymi,

- kosztów alternatywnych (cen dualnych) zastosowania subsydiów rolnych,

- kapitalizacji oraz wycieku subsydiów do otoczenia.

Powinniśmy wystrzegać się, by nakładanie się subsydiów i ich kapitalizacji, procyklicznych zachowań banków oraz inwestycje finansowe w ziemię nie-rolników i kapitału spekulacyjnego nie stymulowały dodatkowo procesów tworzenia się w rolnictwie boom/bust cykli.

Już obecnie KE próbuje nakłonić kraje członkowskie, by w II filarze WPR szerzej sięgały po instrumenty zwrotne (kredyty komercyjne lub subsydiowane, gwarancje i poręczenia kredytowe, wkłady kapitałowe). W przyszłości nie będzie od nich odwrotu. 


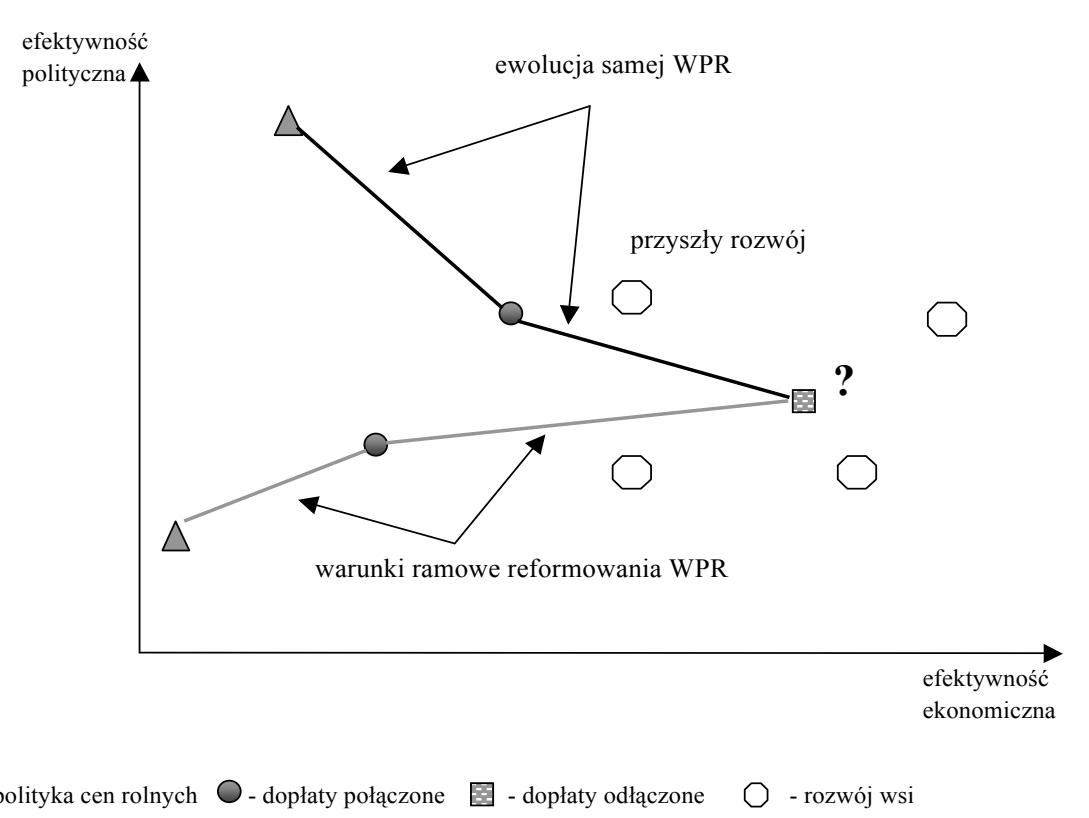

Rys. 1. Efektywność polityczna i ekonomiczna WPR

Źródło: Opracowanie własne na podstawie: Henning, 2005.

\section{Podsumowanie}

Światowy system żywnościowy jest już obecnie w wielu wymiarach niezrównoważony, tak w sferze produkcji, jak i konsumpcji. Stoi przed nim też nadal wiele wyzwań, związanych głównie z rosnącą liczbą ludności (mimo wszystko także przeciętnie bogacącej się), z pogarszaniem się stanu środowiska przyrodniczego i dokonującymi się zmianami klimatu. Będzie rosła zatem konkurencja o zasoby ziemi, wody, surowców energetycznych i mineralnych, niezbędnych do wytwarzania m.in. nawozów potasowych i fosforowych. „Westernizacja" zaś konsumpcji w krajach rozwijających się oznaczać będzie zmiany diety w kierunku większego w niej udziału przetworzonych produktów zwierzęcych, bardziej zasobochłonnych oraz obciążających środowisko przyrodnicze, redukujących bioróżnorodność i przyspieszających antropogeniczną emisję gazów cieplarnianych. Trzeba jednak mocno podkreślić, że w wymiarze globalnym rolnictwo jest jednocześnie częścią zmiany klimatu, ale też szansą jej pohamowania. Prawdopodobna nierównowaga między podażą i popytem na rynkach rolno-żywnościowych mogłaby natomiast bezdyskusyjnie ulec złagodzeniu, gdyby odnotowano wyraźniejszy postęp w redukcji strat i marnotrawstwa w całych łańcuchach żywnościowych. W praktyce jest to trudne, bowiem agrobiznes wciąż będzie funkcjonować w ramach dotychczasowego otoczenia, tak- 
że wielowymiarowo niezrównoważonego, nieuwzględniającego w powszechnej skali efektów zewnętrznych działalności społeczności globalnej. Oznacza to, że konkurencja na międzynarodowych rynkach produktów rolno-żywnościowych nadal będzie opierać się głównie o niskie, tradycyjnie kalkulowane koszty wytwarzania. Procesy te cały czas powinny być uwzględniane w ramach WPR.

Sama WPR, odwołująca się do paradygmatów zrównoważenia i wielofunkcyjności rolnictwa $\mathrm{w}$ sferze formalnej nadbudowy, ma znamiona konstrukcji w miarę nowoczesnej, praktycznej i prospektywnej. Jej wspólnotowy charakter, podobnie jak i innych unijnych polityk, nie zawsze jednak uwzględnia specyficzność położenia poszczególnych krajów członkowskich. Potrzebę jej wyraźnej unifikacji ogólnie uzasadnia się koniecznością zapewnienia równych warunków konkurowania we Wspólnocie. Inna sprawa, że kraje członkowskie mają często problemy $\mathrm{z}$ wykorzystaniem marginesu swobody oferowanego przez Brukselę. Najwyraźniej jest to widoczne w przypadku orientowania instrumentarium polityki rolnej na jednoczesne zadowalające osiąganie celów alokacyjnych (efektywnościowych), redystrybucyjnych (sfera równości) oraz środowiskowych. Często dzieje się tak, że podział wygrywa kosztem efektywności i środowiska przyrodniczego. W dużym stopniu wynika to z preferencji dla subsydiowania jako podstawowego narzędzia rozwiązywania problemów strukturalnych, dochodowych, dostosowawczych i związanych z internalizacją efektów zewnętrznych w rolnictwie i na wsi. Cierpi na tym często tradycyjnie rozumiana konkurencyjność kosztowa, która będzie dominować w Europie nadal w najbliższych latach. Niskie koszty wytwarzania, liczone tradycyjnie oraz także przy uwzględnieniu efektów zewnętrznych, nigdy nie stracą zresztą swego podstawowego znaczenia jako źródło budowy przewagi konkurencyjnej. Rozległe subsydiowanie rolnictwa UE i większości krajów OECD prowadzi ponadto do niezrównoważenia tego sektora w krajach rozwijających się, utrudniając im skuteczne konkurowanie na rynkach międzynarodowych i rozwiązywanie nabrzmiałych problemów rozwojowych oraz trwałe wyrwanie się z zaklętego kręgu biedy i ubóstwa. 


\section{Bibliografia:}

Anderson, K., Rausser, G., Swinnen, J. (2013). Political economy of public policies:insights from distortions to agricultural and food markets. Journal of Economic Literature, $n r$ 51(2).

Beddington, J. (2012). Achieving food security in the face of climate change. Final report from the Commision on Sustainable Agriculture and Climate Change, CGAR, Denmark.

Blankart, Ch.B. (2011). Öffentliche Finanzen in der Demokratie. Eine Einfühnung in der Finanzwissenschaft, 8. Auflage, Verlag Franz Vahlen, München.

Brümmerhoff, D. (2011). Finanzwissenschaft, 10. Auflage, Oldenbourg Verlag, München.

Endres, A. (2013). Umweltökonomie, 4. Aaktualisierte und erweiterte Auflage, Verlag Franz Vahlen, München.

Escalante, C.L., Turvey, C.G., Barry, P.J. (2009). Farm business decisions and the sustainable growth challenge paradigm. Agricultural Finance Review, $n r$ 69(2).

EU-Agrarpolitik nach 2013. Plädoyer für eine neue Politik für Ernährung, Landwirtschaft und ländlische Räume (2010). Berichte über Landwirtschaft, $n r$ 88(2).

Fees, E., Seeliger, A. (2013). Umweltökonomie und Umweltpolitik, 4. Auflage, Verlag Franz Vahlen, München.

Firbank, G.L., Elliot, J., Drake, B., Cao, Y., Gooday, R. (2013). Evidence of sustainable intensification among British farms. Agriculture Ecosystems and Environment, $n r 173$.

Franks, R.J. (2014). Sustainable intensification: A UK perspective. Food Policy, $n r 47$.

Fritsch, M. (2014). Marktversagen und Wirtschaftspolitik, 9. Auflage, Verlag Franz Vahlen, München.

Glebe,T.(2001). Optimale Vertragsdifferenzierung in der Agrarumweltpolitik.Agrarwirtschaft, $n r$ 55(4).

Godfray, J.Ch.H., Beddington, R.J., Crute, R.I., Haddad, L., Lawrence, D., Muir, F.J., Pretty, J., Robinson, S., Thomas, M.S., Toulmin, C. (2010). Food security: The challenge of feeding 9 billion people. Science, $n r 327$.

Godfray, J.Ch.H., Garnet, T. (2014). Food security and sustainable intensification. Philosophical Transactions of the Royal Society B, nr 369.

Henning, A.C.H.Ch. (2001). Agrarsubvention: Politikversagen oder politökonomische Rationalität? W: G . Färber, B. Seidel (Hrsg.), Subwentionspolitik. Führt eine andere Subventionspolitik endlich zum Erfolg? New York, München, Berlin: Waxmann, Minster.

Henning, A.C.H.Ch., Struve, C., Brockmeier, M. (2008). Die Logik der europäischen Agrarpolitik: Politische Macht oder ökonomische Gesetzmäßigkeiten? Agrarwirtschaft, $n$ r 57(3/4).

Henning, A.C.H.Ch. (2005). The show must go on: Zur politischen Ökonomie der Ländlichen Entwicklungspolitik in der EU. Agrarwirtschaft, $n r$ 54(4).

Kissinger, H. (2014). World Order. Published by the Penguin Press, New York.

Kornai J. (2014). Dynamizm, rywalizacja i gospodarka nadmiaru. Dwa eseje o naturze kapitalizmu. Kraków: Fundacja Gospodarki i Administracji Publicznej.

Kowalski, K. (2015). Gruby problem z kilogramami. Rzeczpospolita, 9(10038), s. A7.

Kowalski, A., Wigier, M., Dudek, M. (red.) (2014). Nowa polityka rolna UE - kontynuacja czy rewolucja? Warszawa: IERiGŻ-PIB. 
Kurzstellungnahme zur Mitteilung der Europäischen Komission über die Ausgestaltung der Gemeinsamen Agrarpolitik bis 2020. Berichte über Landwirtschaft, nr 89(1) 2011.

Mußhoff, O., Hirschauer, N. (2011). Modernes Agrarmanagement. Betriebswirtschaftliche Analyse- und Planungsverfahren. 2 Auflage, Verlag Franz Vahlen. München.

Prandecki, K. (red.) (2014). Z badań nad rolnictwem społecznie zrównoważonym (25). Produktywność wybranych form rolnictwa zrównoważonego. Warszawa: IERiGŻ-PIB.

Ripol-Bosh, R., Diez-Unguera, B., Ruiz, R., Villalba, D., Molina, E., Joy, M., Olaizola, A., Bernués, A. (2012). An integrated sustainability assessment of mediterranean sheep farms with different degrees of intensification. Agricultural Systems, $n r 105$.

Sandel, M. (2012). Czego nie można kupić za pieniądze. Warszawa: Kurhaus.

Stefanicki, R. (2015). Świat wychodzi z biedy. Gazeta Wyborcza, . 10.07.2015.

Smith, P. (2013). Delivering food security without incriasing pressure on land. Global Food Security, $n r 2$.

The Hague Conference on Agriculture Food Security and Climate Change. „ClimatSmart" Agriculture. Policies Practices and Financing for Food Security Adaptation and Mitigation, FAO, Rome, 2010.

The Millennium Development Goals Report 2015, United Nations, New York 2015.

Ulanowski T. (2015). Zagłada dinozaurów to drobiazg Gazeta Wyborcza, 8.07.2015.

Zegar, J.S.(red.) (2014). Z badań nad rolnictwem społecznie zrównoważonym (23). Warszawa: IERiGŻ-PIB.

Zegar, J.S. (2012). Współczesne wyzwania rolnictwa. Warszawa: Wydawnictwo Naukowe PWN.

Zimmerman, H., Henke, K.D., Broer, M. (2012). Finanzwissenschaft. Eine Einführung in der Lehre von der öffentlichen Finanzwirtschaft, 11 Auflage, Verlag Franz Vahlen. München. 
JACEK KULAWIK

Institute of Agricultural and Food Economics

- National Research

Warsaw

\title{
GLOBAL AND EUROPEAN DETERMINANTS OF THE CAP
}

\begin{abstract}
The paper, primarily, aims at presentation of the selected global and intra-European determinants of planning, running, updating and reforming the Common Agricultural Policy (CAP) of the European Union. These determinants form a dynamic system of interactions of complementary (synergies), but also contradictory (substitutability) character, with the addition of intrinsic dilemmas of the CAP, which are typical for each sectoral economic policy. Such a broad outlook is justified by the deepening interdependencies in the modern world and the significance of the EU as the largest economic player on the global scale. The CAP is continually at interest of other countries as a source of inspiration but also a precautionary tale as it comes to the undesired effects of widespread state interventionism.

The paper is a cross-sectional study - though having some features of meta-analysis - which synthesises the works of other researchers and own thoughts of the author. All these deliberations led to the conclusion that the $C A P$ - for years appealing to the paradigms of sustainability and multifunctionality of agriculture - bears features of a rather modern utilitarian construct oriented at the future. However, its strong dependence on subsidies makes it a rather unattractive proposal for most of the developing countries, even hindering the process of solving serious development problems. Furthermore, agricultural subsidies deform competition in the international agri-food markets. They also weaken the motivation of the EU farmers to try to improve their competitive position by entrepreneurial behaviours, implementation of innovations, sound cost monitoring and adequate and flexible operating, financial and risk-management strategies.
\end{abstract}

Key words: determinants, Common Agricultural Policy (CAP), competitiveness, state interventionism, sustainability of agriculture, climate change, agri-food market, emissions, food security

Zaakceptowano do druku - Accepted for print: 03.12.2015. 